\title{
Sin nombre de autor: anónimos y rumores en los impresos del período cisplatino
}

\author{
Wilson González Demuro \\ Universidad de la República
}

Recibido: 30/10/2016

Aceptado: 29/11/2016

\section{Resumen}

Este artículo examina la presencia del rumor y los anónimos en los impresos del período cisplatino en la ciudad de Montevideo. Comienza con una caracterización general de ambas modalidades de comunicación. Luego de examinar brevemente algunos antecedentes históricos se enfoca en el análisis de la publicística del lapso 1821-1826, cuando la misma era solo montevideana debido a la inexistencia de imprentas fuera de la ciudad. Procuramos conocer de qué manera las voces, versiones $\mathrm{y}$ diferentes textos de autor desconocido (aunque muchas veces sospechado) se combinaron en los impresos, cómo fueron utilizados por los editores, qué valoración hicieron ellos de su propia praxis anónima y las reacciones producidas por algunas publicaciones a nivel gubernamental.

Palabras clave: prensa - rumor - escritura anónima

\section{Nameless: anonymous and rumors in Cisplatine press}

\begin{abstract}
This article examines the presence of rumor and anonymous in the Cisplatin press in Montevideo city. It begins with a general characterization of both modalities of communication. After briefly examining some historical antecedents, it focuses on the analysis of Montevideo's printings between 1821-1826, a time when there was no press outside this city. We tried to know how the voices, versions and different texts of unknown -but often suspected - authors were combined in the press, how they were used by publishers, what evaluation they made of their own anonymous praxis and the government reactions caused by some publications.
\end{abstract}


Key words: press - rumor - anonymous writing

\section{Introducción}

A comienzos del siglo XIX los dispositivos tradicionales de comunicación experimentaron profundos cambios en Iberoamérica. En el contexto de crisis que atravesaban las monarquías portuguesa y española se incrementó notablemente la producción de textos. Esta multiplicación se debió no solo a la actividad de las élites ilustradas; si bien estas desempeñaron un papel protagónico, otros sectores también contribuyeron de diferentes modos con la expansión de la llamada cultura impresa. ${ }^{1}$ Como señalara François-Xavier Guerra en un conocido artículo, "la iniciativa de la palabra [provino] de la sociedad o, más precisamente, del cuerpo político, con una libertad de tono desconocida hasta entonces". ${ }^{2}$

Dos herramientas muy antiguas y estrechamente vinculadas entre sí, el rumor y la escritura anónima, fueron ampliamente usadas en la nueva etapa. En esta oportunidad intentaremos conocer de qué forma impactaron en la actividad de imprenta cisplatina durante el período en que esta fue únicamente montevideana (1821-1826). Dicho de otro modo, no se trata de un estudio específico sobre el rumor y la anonimia sino de examinar la presencia de ambos (y eventualmente su importancia) en la comunicación impresa. ${ }^{3}$ Escogemos este tramo del ciclo revolucionario por razones de orden cuali-cuantitativo. El número más alto y la mayor variedad de impresos producidos en Montevideo a partir de la aprobación de la ley de imprenta de 1821 permiten detectar con mayor facilidad la presencia

\footnotetext{
${ }^{1}$ De acuerdo con la definición de William Acree, diremos que "la cultura impresa se forma a través de los vínculos que conectan los públicos lectores - tanto alfabetizados como analfabetos- con los medios impresos y los textos, lo que a menudo va más allá de la palabra escrita. Más específicamente, concierne a las relaciones entre las prácticas de lectura y escritura, por un lado, y a las conductas sociales, los valores individuales y colectivos, las transacciones económicas, las decisiones políticas, las instituciones estatales, y las ideologías, por el otro. El estudio de la cultura impresa, cuyo foco principal es la palabra impresa en todas sus manifestaciones, también abarca, por ejemplo, la imagen que aparece en un periódico o revista, el pasquín o la publicidad colocada en la plaza del pueblo, el uso de retratos en los billetes y las estampillas postales, el acto de leer en voz alta para un grupo de gauchos en la pulpería o para soldados analfabetos apiñados en una trinchera, y los adornados lemas que amantes, esposas y madres cosían en las vinchas que usaban los soldados en toda América Latina durante el siglo XIX. Los términos lectura y públicos lectores adquieren, así, un significado mucho más profundo, mucho más inclusivo". (ACREE, William, La lectura cotidiana. Cultura impresa e identidad colectiva en el Río de la Plata, 1780-1910, Buenos Aires, Prometeo, 2013, p. 16).

${ }^{2}$ GUERRA, François-Xavier, "«Voces del pueblo». Redes de comunicación y orígenes de la opinión en el mundo hispánico (1808-1814)”, Revista de Indias, vol. LXII, nº 225, 2002, pp. 359-360.

${ }^{3}$ Un estudio profundo el rumor requiere analizar ciertas fuentes con las que aquí no trabajaremos como los expedientes judiciales, y la participación de ciertos actores clave en la circulación de especies durante los períodos revolucionarios (curas y militares, entre otros).
} 
interactiva de estas formas de comunicación. Asimismo, con la aparición en Canelones de la independentista Gaceta de la Provincia Oriental (noviembre de 1826), la actividad de imprenta traspasó por primera vez el antiguo límite montevideano, dando inicio a un movimiento político-editorial novedoso, intenso, de alcance provincial y con características lo bastante singulares como para merecer un análisis separado del que aquí presentaremos.

La prensa periódica y otros impresos correspondientes al lapso referido serán los principales insumos documentales. Dividiremos la exposición en tres partes: las dos primeras, más breves, presentarán algunas definiciones y antecedentes sobre el rumor y los anónimos en la sociedad hispanoamericana, y en la tercera nos abocaremos al tema central del artículo. Retomaremos aquí algunos temas y problemas ya abordados en nuestra tesis de maestría, texto que actualmente se encuentra en vías de publicación. ${ }^{4}$

\section{Definiciones}

En una conferencia pronunciada en 2013, la historiadora Frédérique Langue examinó ciertas peculiaridades de los estudios sobre el rumor en las revoluciones hispanoamericanas. Según la autora, se trata de un elemento sumamente "escurridizo", que por su propia naturaleza suele no aparecer con claridad en las fuentes y se desplaza fácilmente hacia "los márgenes del método histórico". Como medio de comunicación, el rumor está ligado a un imaginario social, político y religioso, específico y persistente, y también brinda señales, aunque no pruebas concluyentes, sobre ciertos niveles de información y desinformación característicos de un colectivo durante lapsos más o menos variables. Suele constituir, además, un "mecanismo de transgresión y de expresión de grupos o sectores sociales que no siempre se beneficiaron de una verdadera representación política”. Actúa como indicador de sensaciones fundamentalmente negativas, como el miedo y el resentimiento, y es vehículo eficaz para la divulgación rápida de malas noticias tanto de orden personal/singular como colectivo. En su dimensión "sediciosa", el rumor de los tiempos revolucionarios posee un componente emocional que hace enteramente

\footnotetext{
${ }^{4}$ GONZÁLEZ DEMURO, Wilson, La prensa de Montevideo, 1814-1825. Imprentas, periódicos y debates públicos en tiempos de revolución (inédito).
} 
imprescindible su contextualización "como paso previo hacia la crítica de las fuentes tal como la practican los historiadores de oficio". 5 A propósito de ello, James Scott nos recuerda que todo rumor, más allá de las circunstancias en que nace y se difunde, va incorporando, transformando o perdiendo componentes de acuerdo a las visiones del mundo, las esperanzas y los temores propios de quienes lo reciben $\mathrm{y}$ retransmiten. ${ }^{6}$

Desde una perspectiva fundamentalmente comunicacional, Margarita Zires ha reflexionado sobre el rumor como manifestación oral y el desafío de analizarlo a través de textos. Al comparar los mensajes escritos con aquellos que se expanden "cara a cara" o "boca a boca", identifica tres posibles dimensiones del rumor: oral, colectiva y anónima. Con respecto a la primera, la comunicación escrita da cuenta de cierta distancia temporal entre los actos de emitir y recibir -alguien produce un texto que otro(s) leerá(n) posteriormente- que no está presente en la transmisión oral, donde ambas acciones son simultáneas. En el mismo sentido, emisor y receptor de un escrito generalmente no están en contacto físico, algo que sí ocurre en la oralidad. Igualmente, la apoyatura gestual que falta en la comunicación mediante textos es habitual en el intercambio oral, donde los mensajes son recibidos al mismo tiempo por distintas vías (auditiva, visual, táctil, etcétera). Al referirse a la "dimensión colectiva del rumor", Zires destaca sus diferencias con el simple chisme, "en tanto [aquel] cruza o atraviesa las barreras de los grupos sociales y no sólo versa sobre asuntos de terceras personas". 7 En cuanto a la dimensión anónima, se entiende que si bien es cierto que un rumor pudo originarse como proyecto manipulador no es esto lo que lo constituye, "sino la dinámica de variación que se genera al ponerse en circulación". Voz sin nombre ni credenciales que lo identifiquen, carece de centro, "o más bien es policéntrico". Siempre otorga a su emisor (un individuo o varios) la opción de esconderse en la masa de hablantes-oyentes. El se dice con el que suele presentarse remite a un presente, a un tiempo contemporáneo del hablante-oyente.

\footnotetext{
${ }^{5}$ LANGUE, Frédérique, “«Del pasado hay que hacer añicos». Historiadores, prensa y revolución en Venezuela”, Nadia AÏT BACHIR (ed.), Las fuentes en la prensa: verdades, rumores y mentiras, Burdeos, Département d'Études ibériques, ibéro-américaines \& méditerranéennes / UFR Langues et civilisations, Université Michel de Montaigne-Bordeaux 3, 2013, pp. 11-12.

${ }^{6}$ SCOTT, James, Los dominados y el arte de la resistencia, México, Ediciones ERA, 2000, p. 176.

${ }^{7}$ Scott, por su parte, considera que "el chisme es casi siempre, antes que nada, un discurso sobre la infracción de reglas sociales". La persona/grupo/institución acusada de cometer alguna falta verá su reputación dañada "solo si quienes participan en la circulación de los chismes comparten normas" comunes sobre los temas en cuestión. Sin ellas, ese mecanismo de difusión pierde sentido, pero si existen, el chisme muy probablemente las reforzará (SCOTT, James, ob. cit., pp. 173-174).
} 
El rumor que funciona no evoca pasados sino el momento en que se difunde. Implícitamente, el se dice alude a un se oye, a bocas y oídos en contacto; lo que destaca al emplearse el pronombre se, precisamente, es la naturaleza genérica del sujeto. 8

Natalia Silva Prada analiza la escritura anónima como "práctica de uso común, e incluso necesaria, en el desarrollo de la vida política del antiguo régimen". Una sociedad tan fuertemente jerarquizada como aquella encontraba en las formas secretas de comunicación (de las que el rumor y el escrito anónimo forman parte) una herramienta de suma utilidad. El escrito anónimo, probablemente generalizado en la publicística desde el siglo XVI, se impuso como modalidad de difusión casi exclusiva por lo menos hasta finales del XVIII, cuando el auge de las imprentas potenció sus alcances. Desde entonces, la concurrencia de diversos factores (legislación destinada a delimitar responsabilidades políticas, intereses comerciales de editores y libreros o reclamos eclesiásticos contra textos herejes y heterodoxos) iría imponiendo progresivas restricciones a esta vía de comunicación. ${ }^{9}$

Como parte de sus estudios de historia social, de la clase trabajadora y del movimiento obrero inglés, Edward Thompson analizó la "carta anónima de amenaza" como una estrategia usada "para el agravio personal y como instrumento de extorsión". Sus comprobaciones tienen singular relevancia, más allá de que la temática, la base heurística y los objetivos de su trabajo hayan sido diferentes de los nuestros. En efecto, uno de los propósitos con que fueron elaborados los anónimos estudiados por Thompson nos interesa particularmente: la crítica contra las altas autoridades políticas o religiosas, dotada de una acidez rayana con el insulto, o decididamente agraviante. Esta clase de escritos fue cultivada por sectores sociales que entre los siglos XVIII y XIX superaron cierto nivel de alfabetización pero aún tenían formas débiles de defensa colectiva organizada. En virtud de ello, eran frecuentemente acusados de promover protestas y blanco probable de la represión. Pero hay algo más: en un contexto en el que predominaban las "relaciones de paternalismo y deferencia, dominio y subordinación”, existían muchas razones para

\footnotetext{
${ }^{8}$ ZIRES, Margarita, "Las dimensiones del rumor: oral, colectiva y anónima", Oralidad, anuario 8. Lenguas, identidad y memoria de América, La Habana, UNESCO - Editorial Pueblo y Educación, 1996, pp. 23-28.

9 SILVA PRADA, Natalia, "La escritura anónima: ¿especie sediciosa o estrategia de comunicación política colonial?”, Andes. Antropología e Historia, n 16, 2005, pp. 223-229.
} 
mantener el anonimato, y este "de ninguna manera [fue] el refugio de los pobres exclusivamente". El autor halló fondos documentales pertenecientes a individuos de la élite o vinculados al gobierno en los que no fue extraña la mezcla de piezas de autor perfectamente reconocible, con otras que parecen más propias de "una sociedad de seres furtivos y de delatores". ${ }^{10}$ Esta suerte de "visión doble" también se puso de manifiesto al cotejar cartas amenazadoras o infamantes y lo publicado en "la prensa permitida o los periódicos de los grandes" ${ }^{11}$, esto es, la publicidad más sujeta a reglas formales.

Al igual que Thompson, es decir, desde una perspectiva no centrada en el rumor y el anonimato como estrategias comunicacionales del independentismo decimonónico, el estudio de James Scott sobre el discurso político de los sectores dominados también aporta elementos válidos para el análisis. El antropólogo estadounidense define dichas prácticas como una "política del disfraz y del anonimato que se ejerce públicamente, pero que está hecha para contener un doble significado o para proteger la identidad de los actores". Ella es capaz de reunir "perfectamente los rumores, los chismes, los cuentos populares, los chistes, las canciones, los ritos, los códigos y los eufemismos: en fin, buena parte de la cultura popular de los grupos subordinados", distinguiéndose claramente del "discurso público" hecho "para impresionar, para afirmar y naturalizar el poder de las élites dominantes, y para esconder o eufemizar la ropa sucia del ejercicio de su poder". ${ }^{12} \mathrm{Si}$ nos atenemos a la categorización propuesta por Scott, veremos que la utilización por parte de la élite rioplatense de recursos comunicacionales propios de los sectores subordinados no fue nada excepcional.

\section{Antecedentes}

En 1564 se conoció la quinta y última parte de Pantagruel, la extensa obra satírica que François Rabelais comenzó a publicar en 1532. En ella aparece una personificación del rumor, representado por un anciano achacoso y de aspecto poco amable, descripto por Lucien Febvre en los siguientes términos:

\footnotetext{
10 THOMPSON, Edward, "El delito de anonimato", Tradición, revuelta y consciencia de clase, Barcelona, Crítica, 1984, pp. 173-174 y 194.

${ }^{11}$ Ibídem, p. 238.

${ }^{12}$ SCOTT, James, ob. cit., pp. 42-43.
} 
"el rumor [es] ciego y paralítico, lleno de orejas siempre enormemente abiertas y provisto de siete lenguas que se agitan al unísono en sus negras fauces. Recibe con todas sus orejas y comunica con todas sus lenguas a auditorios boquiabiertos que ni controlarán ni criticarán ni comprobarán todo ese disparatado saber que inunda libros y gacetas".13

En la simbología rabelesiana el rumor era, pues, un hombrecillo viejo pero aún impresionante, que encarnaba un "saber disparatado" donde se mezclaban las informaciones más diversas. Circulaba sin controles ni verificación, se esparcía entre individuos que muchas veces estaban dispuestos a aceptar, sin más, lo que se les ofrecía como noticia extraordinaria, y podía finalmente llegar a todos los impresos. Era, en suma, un mecanismo de comunicación capaz de influir fuertemente en la formación de opiniones colectivas, tanto en su primitiva forma oral como en las versiones escritas de amanuenses o tipógrafos.

El interés de Rabelais por los rumores era también el de muchas otras personas, comenzando por las de más alta posición. La Europa del Quinientos mostró un fuerte y muchas veces preocupado interés por la influencia que aquellos pudieran alcanzar. Entre las múltiples formas que asumían hubo algunas, como las que concernían al honor y la reputación de las autoridades, que atrajeron especialmente la atención general. A lo largo de ese siglo se multiplicaron las medidas dirigidas a controlar $-\mathrm{y}$ en lo posible erradicar- la tradición de esparcir especies sobre instituciones y personajes públicos. Fueron vistas generalmente con fastidio y temor desde el poder. El propio Felipe II condenó en 1591 los "atroces", "graves” y "muchos pasquines y libelos infamatorios", que "echa[dos] por las calles y pu[estos] por las esquinas de las plazas y calles públicas" se unían a las leyendas pintadas en muros con el evidente propósito de atacar a los "principales ministros y [a] los del Santo Oficio de la Inquisición e Inquisidores”, y "conmover más y levantar al pueblo”. ${ }^{14}$ Las medidas de vigilancia y represión más contundentes estuvieron dirigidas inicialmente contra la difusión de críticas y burlas a las autoridades de la Iglesia (Sínodo de Astorga, 1553), pero en poco tiempo abarcaron también la esfera civil en la medida que aquellas fueron extendiéndose progresivamente a este campo.

\footnotetext{
${ }^{13}$ FEBVRE, Lucien, El problema de la incredulidad en el siglo XVI. La religión de Rabelais, Madrid, Akal, 1993, p. 269.

${ }^{14}$ Citado por CASTILLO GÓMEZ, Antonio, "Desde el muro. Formas y mensajes de la escritura expuesta en la ciudad altomoderna", Gemma PUIGVERT y Carme DE LA MOTA (ed.), La investigación en Humanidades, Madrid, Editorial Biblioteca Nueva, 2009, p. 98.
} 
Ya en el siglo XVII, con las semiletradas sociedades ibérica e hispanoamericana adjudicando a los escritos una importancia mayor, aumentó también el temor al daño que pudieran causar las denuncias que circulaban entre el papel y la oralidad, o viceversa. "La calle y la palabra, hablada o escrita", señala Castillo Gómez, fueron "el espacio y la tecnología empleados para difundir opiniones” en asuntos de religión, política, o simplemente de orden personal, centradas en la moral o la ética de determinados individuos. ${ }^{15}$ En el protoespacio público de calles y plazas, examinado por Michele Olivari en un detallado estudio, pudieron articularse las nociones de publicidad y lugar de uso común libre. Individuos poderosos e instituciones tradicionales tenían serias dificultades para limitar el "derecho a las calles", que solo pertenecían al rey, de modo que estaban fuera del alcance de los privilegios particulares y habilitaban la proliferación a nivel popular de rumores y pasquines que se colgaban en puertas o paredes. Para denunciar las arbitrariedades de cierto tirano, el dramaturgo valenciano Guillén de Castro escribió a comienzos del siglo: "ya el rigor de tu justicia / yuzgada [sic] dudosamente / ...y ya con tener oídos / de las calles las paredes / tienen bocas, tienen lenguas / para que de ti se quejen / entre el confuso alboroto / que se levanta en la gente”. ${ }^{16}$

El notable desarrollo de la publicística dieciochesca ibérica tuvo a su favor dos factores, la multiplicación de los talleres tipográficos y la coyuntura política. En un exhaustivo trabajo sobre la publicidad durante la Guerra de Sucesión Española, David González Cruz demuestra que tanto los austracistas como los felipenses apelaron a todas las variantes posibles de comunicación escrita, incluyendo la impostura de individuos cercanos o pertenecientes a la élite que "camuflaron" o “popularizaron” su lenguaje para redactar versos anónimos, libelos y pasquines que “resultaran muy fáciles de comprender y ofrecieran apariencia de sencillez" a las masas populares. ${ }^{17}$ Para examinar las formas en que se difundían las noticias, rumores y trascendidos de toda clase debe recordarse también que en este siglo tuvo

\footnotetext{
15 CASTILlO GÓMEZ, Antonio, "Panfletos, coplas y libelos injuriosos. Palabras silenciadas en el Siglo de Oro", Manuel PEÑA DÍAZ (ed.), Las Españas que (no) pudieron ser: herejías, exilios y otras conciencias (s. $X V I-X X)$, Huelva, Servicio de Publicaciones de la Universidad de Huelva, 2009, pp. 59-66 y 71.

${ }^{16}$ OLIVARI, Michele, Avisos, pasquines y rumores. Los comienzos de la opinión pública en la España del siglo XVII, Madrid, Cátedra, 2014, pp. 23-26.

${ }^{17}$ GONZÁLEZ CRUZ, David, Propaganda e información en tiempos de guerra. España y América (17001714), Madrid, Sílex, 2009, pp. 80-81. En plena guerra, el arzobispo de Zaragoza admitía que los escritos "vulgares", habitualmente despreciados por los "cuerdos, prudentes y advertidos", resultaban sumamente eficaces para "captar la benevolencia de los vulgares (que son los más)” (citado en ibídem, p. 80, n. 184).
} 
lugar una acelerada urbanización, combinada con niveles de alfabetización todavía modestos. Al indagar la desaparición de niños en la París prerrevolucionaria, Arlette Farge y Jacques Revel se encontraron repetidas veces con "el rumor [como] parte intrínseca de la vida en la ciudad", algo que las propias autoridades reconocían. En efecto, un jerarca policial debió admitir que "los parisinos estaban más inclinados a creer en los falsos informes y libelos que circulaban clandestinamente que en los informes impresos y publicados por orden del gobierno" ${ }^{18}$ Conviene señalar, además, que el vocablo rumor llegó cargado de polisemia al final de la centuria. Según el diccionario de Terreros y Pando (1788), significaba "ruido, murmullo" y al mismo tiempo "barahúnda". También era "cierta noticia vaga, incierta", así como "riña, sedición, tumulto", de modo que en el habla colectiva esta palabra podía representar, quizás imbricadas, las ideas de secreto, confidencialidad, incertidumbre, falsedad, desorden e incluso caos. ${ }^{19}$

En el Río de la Plata, como en otras partes de Hispanoamérica, crecieron a comienzos del siglo XIX el número y la importancia de tertulias, sociedades literarias y cafés, aunque las normas vigentes a fines del dominio hispánico restringieron la presencia de los sectores populares en esos ámbitos. De acuerdo con Pilar González, que tales sitios hayan quedado casi exclusivamente reservados a la "clase decente" parece haber influido en las modalidades de politización que adoptó la plebe. ${ }^{20}$ Resulta particularmente interesante el caso de los cafés y otros centros de reunión menos apreciados por las élites, y también poco estudiados, como los salones de juego, de los que hubo varios en Montevideo. Según un cronista desconocido, solían hallarse "atestados de gente" que jugaba "con furor" a los naipes o al billar, muchas veces por dinero. ${ }^{21}$ Teniendo en cuenta la experiencia de sus pares bonaerenses, es probable que también en la Banda Oriental hayan resultado importantes en la

\footnotetext{
${ }^{18}$ Citado por FARGE, Arlette; REVEL, Jacques, The Vanishing Children of Paris. Rumor and Politics before the French Revolution, Cambridge (Mass.), Harvard University Press, 1991, p. 95.

19 TERREROS Y PANDO, Esteban, Diccionario castellano con las voces de ciencias y artes, y sus correspondientes en las tres lenguas francesa, latina e italiana, Madrid, Imprenta de la Viuda de Ibarra, Hijos y Compañía, 1788, p. 406.

${ }^{20}$ GONZÁLEZ BERNALDO, Pilar, "La Revolución Francesa y la emergencia de nuevas prácticas de la política: la irrupción de la sociabilidad política en el Río de la Plata revolucionario, 1810-1815", Boletín del Instituto de Historia Argentina y Americana "Dr. Emilio Ravignani", $3^{\mathrm{a}}$ serie, $\mathrm{n}^{\circ} 3$ 3, 1991, pp. 12-13. "En todo caso", esta forma de segregación "contribuy[ó] a dificultar la organización de sociedades políticas populares, si acaso fue esta la intención de la juventud revolucionaria acusada de "jacobina" (p. 13).

${ }^{21}$ Citado por BENTANCUR, Arturo, La familia en el Río de la Plata a fines del período hispánico. Historias de la sociedad montevideana, Montevideo, Planeta, 2011, p. 29.
} 
difusión de comentarios sobre acontecimientos de todo tipo, algunos conocidos a través de impresos y otros por simple transmisión oral. No sorprende entonces que el cambio de clima ocasionado por la crisis monárquica haya puesto en alerta al gobierno virreinal, a tal punto que en 1809 el virrey Cisneros mandó castigar a quienes en "cafés y casas públicas" recurrieran a rumores, "pasquines" y "papeles anónimos" para esparcir juicios negativos sobre las autoridades o para "insulta[r] a sus conciudadanos”. ${ }^{22}$ Desde 1810, la revolución y la guerra operaron como factores claves del perfil de la cultura impresa rioplatense. Por lo menos hasta 1830, destaca Acree, todas las formas de escritura -incluidos los pasquines, impresos o manuscritos - funcionaron como armas de guerra. La palabra impresa fue un "signo tangible de legitimidad" que influyó notablemente en la apertura de espacios de interacción entre las élites y los sectores populares. Estos sumaban algunos letrados y grupos iletrados que a partir de lecturas públicas promovían debates y reinterpretaciones propias. ${ }^{23}$

\section{El anónimo y los rumores en las publicaciones del período cisplatino}

La segunda invasión portuguesa a la Provincia Oriental se inició en 1816 y tuvo dos momentos culminantes, uno en enero de 1817, cuando las tropas comandadas por el capitán general Carlos Federico Lecor ocuparon Montevideo, y otro en enero de 1820, con la definitiva derrota del artiguismo en Tacuarembó. Ambos episodios, íntimamente ligados, fueron celebrados como una victoria propia por los sectores de la élite oriental que apoyaron la intervención pacificadora del ejército luso-brasileño. El comienzo de la década de 1820 estuvo signado por algunos hechos próximos y otros, solo en apariencia, lejanos: los alzamientos liberales ibéricos -fugazmente exitosos-, la independencia del Brasil y los procesos de construcción estatal en las antiguas provincias del virreinato rioplatense. ${ }^{24}$ Una de las consecuencias directas del transitorio triunfo del liberalismo en Portugal fue la aprobación de la Ley de Libertad

\footnotetext{
22 Citado en GARAVAGLIA, Juan Carlos, "Los primeros senderos de la revolución: La Opinión en los balbuceos de la Independencia rioplatense (1806-1819)”, Izaskun ÁLVAREZ CUARTERO; Julio SÁNCHEZ GÓMEZ (ed.), Visiones y revisiones de la independencia americana, Salamanca, Ediciones de la Universidad de Salamanca, 2003, p. 133. Sobre las diversas clases de pasquines circulantes en los años previos a la revolución: DÍAZ, César L., Comunicación y revolución, 1759-1810. Esfera y espacio público rioplatense: periodismo, censura, prácticas y ámbitos de lectura, La Plata, Universidad Nacional de La Plata, 2012, pp. 162-186.

${ }^{23}$ ACREE, William, ob. cit., pp. 29-30.

24 Para una síntesis del proceso político de 1810-1821, véase FREGA, Ana, "La vida política", Gerardo CAETANO (dir.), Ana FREGA (coord.), Uruguay: revolución, independencia y construcción del Estado. Tomo I, 1808/1880, Montevideo, Mapfre, 2015, pp. 40-55.
} 
de Imprenta, en julio de 1821. La norma reguló, o al menos orientó lo principal de la actividad tipográfica en la provincia durante toda la década. Sus antecedentes inmediatos se encuentran en tres decretos expedidos por el gobierno luso en 1820 (21 de setiembre y 13 de octubre) y 1821 (9 de marzo), herederos a su vez de los principios establecidos en Cádiz (1810-1812). ${ }^{25}$ En Brasil, esta nueva legislación produjo un salto cuantitativo mayúsculo con la aparición de una decena de periódicos donde hasta entonces solo había existido Gazeta do Rio de Janeiro. ${ }^{26}$ Similar despegue, aunque bajo otras circunstancias, experimentó la publicística montevideana.

Al tiempo que definió la libertad de imprenta como "el apoyo más seguro del sistema constitucional", la ley estableció disposiciones claras sobre las responsabilidades de escritores y tipógrafos, entendiendo que libertad y licencia (o abuso) eran conceptos antagónicos. Se determinó que "toda persona p[odía] imprimir, publicar, comprar, y vender en los Estados Portugueses cualesquiera libros o escritos sin previa censura", debiendo constar claramente en cada obra "el lugar y año de la impresión, y el nombre del impresor". Además, "el autor o editor de escritos impresos en los Estados Portugueses, y el impresor de ellos, cuando no const[as]e quien [fuera] su autor o editor, responder[ía]n por todo el abuso que en ellos se hiciere de la Libertad de Imprenta". La norma también detalló los posibles excesos, su gravedad y los castigos que debían aplicarse en cada caso, fijando cuatro categorías de escritos abusivos: contra el catolicismo, contra el Estado, contra las buenas costumbres y contra los individuos. Mencionemos algunos ejemplos: entre los delitos de imprenta que podían cometerse en perjuicio del Estado figuraban los de "excita[r] a los pueblos directamente a rebelión", "desobedecer las Leyes o las Autoridades constituidas", atacar "la forma del Gobierno representativo, adoptado por la Nación", e "infama[r] o injuria[r] al Congreso Nacional, o al Jefe del Poder Ejecutivo". ${ }^{27}$

\footnotetext{
${ }^{25}$ TENGARRINHA, José, História da imprensa periódica portuguesa, Lisboa, Caminho, 1989, pp. 123-133.

${ }^{26}$ MOREL, Marco, "La génesis de la opinión pública moderna y el proceso de independencia (Río de Janeiro, 1820-1840)", François-Xavier GUERRA, Annick LEMPÉRIÈRE y otros, Los espacios públicos en Iberoamérica. Ambigüedades y problemas. Siglos XVIII y XIX, México, Centro Francés de Estudios Mexicanos y Centroamericanos - Fondo de Cultura Económica, 1998, pp. 301-303. Véase también RIBEIRO, Lavina Madeira, Imprensa e espaço público: a institucionalização do jornalismo no Brasil (1808-1964), Río de Janeiro, E-Papers Serviços Editoriais, 2004.

${ }^{27}$ Biblioteca Nacional, Montevideo. Sala Uruguay (en adelante BNM-SU), Documentos históricos. Bandos, proclamas, manifiestos y otros documentos oficiales correspondientes a los años 1821 a 1823 (en adelante
} 
Al amparo de este marco jurídico - cuya vigencia fue facilitada por la incorporación de la provincia al Reino de Portugal, Brasil y Algarve, con el nombre de Cisplatina- comenzaron a circular en Montevideo impresos que ensalzaron las virtudes de la ley y el espíritu liberal de quienes la habían aprobado. Entre los aún escasos escritores públicos fue vista, en general, como una sana medida contra el despotismo, pero también hubo miradas críticas no sobre el texto legal sino sobre las circunstancias políticas que lo hacían inaplicable, al menos en toda su extensión. Un comunicado anónimo se refirió a la imprenta libre como un arma virtuosa y "mucho más poderosa que la fuerza para atacar la arbitrariedad y contener la licencia”, asegurando que "la felicidad general" estaría protegida y que el ciudadano ya "no [sería] juzgado en el seno del misterio por la prevención, ni maltratado por la mordacidad”. ${ }^{28}$ Pero alguien que utilizó el seudónimo "El Oriental Pacificado" envió una carta al Pacífico Oriental de Montevideo (primer periódico editado tras la aprobación de la ley de imprenta), valorando la situación de otro modo. Opinó que la ausencia de una cultura de interacción entre sociedad y periodistas, así como la desconfianza generada por la presencia de soldados portugueses desestimulaban a los posibles corresponsales:

\footnotetext{
"Hace diez meses que somos constitucionales, y cuatro que somos cisplatinos, sin que esta metamorfosis haya influido lo más mínimo en la marcha de los negocios públicos: todo sigue lo mismo. [Nadie] escribirá libremente, mientras no contemos con otra garantía que la que tenemos, y mientras se vea uno forzado a ocultar su nombre, y fingir la letra para decir verdades". ${ }^{29}$
}

Con algo de candidez, el editor respondió que el problema no estaba en el gobierno "que legalmente ha[bía] otorgado tan precioso derecho", sino en la "demostrada indiferencia [de los] ciudadanos" a la hora de ejercerlo.3o Según el lector, en el Montevideo gobernado por Lecor se escribía en forma anónima no solo por tradición, sino más bien por razones de seguridad que a su juicio eran evidentes. Esos temores se confirmaron solo tres meses más tarde, cuando se produjo un

Documentos históricos), pieza 3. Decreto sobre la extensión de la libertad de imprenta, Montevideo, 1821, artículos $1,4,7,12$ y 13 .

${ }^{28}$ BNM-SU, Documentos históricos, pieza 5. Anuncio de la Ley sobre la Libertad de Imprenta, Montevideo, 1821.

29 Suplemento al número cuarto del periódico Pacífico Oriental de Montevideo, 15 de enero de 1822, s/p, "Cuarto".

${ }^{30}$ El Pacifico Oriental de Montevideo, 12 de abril de 1822, p. 135, s/t. 
episodio que tuvo al propio editor de El Pacífico como protagonista: un militar portugués, ofuscado por comentarios sin firma aparecidos en el periódico, le propinó una golpiza en plena calle. El gobierno no tomó medidas contra el agresor. ${ }^{31}$

La independencia brasileña (setiembre de 1822) motivó la división del ejército ocupante: Lecor, partidario del flamante emperador Pedro I, se instaló fuera de Montevideo y controló la campaña mientras que la portuguesa División de Voluntarios Reales, asentada en Montevideo bajo las órdenes del general Alvaro Da Costa, mantuvo su lealtad al gobierno de Lisboa. A partir de entonces se revitalizó la Sociedad de Caballeros Orientales, logia independentista formada tres años antes con la participación de importantes representantes del elenco político, comercial y militar más influyente, particularmente activos en el Cabildo montevideano. Varios de ellos tuvieron además un importante desempeño como periodistas: Santiago Vázquez, Juan Francisco Giró, Antonio Díaz y Francisco Solano Antuña, a quienes se sumó el maestro valenciano José Catalá y Codina, que al parecer no formó parte de la logia. Ellos fueron los editores conocidos ${ }^{32}$ de órganos como El Pampero, La Aurora, El Ciudadano, El Aguacero y Los Amigos del Pueblo, publicados entre diciembre de 1822 y setiembre de 1823. Pero actuaron además otros escritores de los que por ahora nada sabemos, redactores de numerosos papeles "menores", pasquines, folletos y hojas sueltas que en general criticaron con acidez a Lecor y sus aliados, frecuentemente apodados "el Club", "los aristócratas" o "laguninos". La mayoría de ellos impulsó con insistencia -en particular a través de los órganos más importantes- la ruptura con Brasil y la reincorporación de la provincia a la unión rioplatense.

El quiebre en las filas invasoras y la consecuente división político-territorial de la provincia dispararon la circulación de rumores, comentarios y pronósticos de todo

\footnotetext{
31 Carta de Nicolás Herrera a Lucas Obes, Montevideo, 22 de abril de 1822, citada en CAMPOS DE GARABELLI, Martha, La Revolución Oriental de 1822-1823. Su génesis, tomo I, Montevideo, Junta Departamental, 1972, p. 347. En otra parte hemos estudiado más detalladamente este periódico: GONZÁLEZ DEMURO, Wilson, "La prensa en tiempos de la Provincia Cisplatina. El Pacífico Oriental de Montevideo y los ecos del constitucionalismo portugués en el Río de la Plata", Improntas de la historia y la comunicación, $\mathrm{n}^{\circ} 2$, Universidad Nacional de La Plata, Facultad de Periodismo y Comunicación, diciembre-mayo 2016, pp. 1-33. Disponible en http://perio.unlp.edu.ar/ojs/index.php/improntas/index.

${ }^{32}$ Sus firmas no aparecen en los medios independentistas. Conocemos su actuación por vías indirectas y no siempre confiables en su totalidad: anotaciones en archivos particulares (Antonio Díaz), uso esporádico de iniciales ("S.V.", por Santiago Vázquez), comentarios de sus enemigos políticos, y fundamentalmente a través de las investigaciones sobre la prensa oriental realizadas por Antonio Zinny a fines del siglo XIX (GONZÁLEZ DEMURO, Wilson, La prensa de Montevideo, ob. cit.).
} 
tipo, que ocasionaron la rápida respuesta de unas autoridades que poco podían hacer para evitar su propagación. Dentro y fuera de Montevideo, quienes aún se mantenían leales al lecorismo alertaron sobre este problema. En noviembre de 1822, poco antes que algunos de sus miembros cuestionaran formalmente el carácter cisplatino de la provincia33, el Cabildo condenó que "algunos malintencionados propaga[se]n falsas especies, que pu[diera]n perturbar la tranquilidad pública". La "malicia de personas interesadas [tanto] en perturbar el sosiego, como en adormecer el espíritu público", era algo que "conv[enía] destruir". ${ }^{44}$ Aparte de la condena en términos políticos, o de otro orden según fuera el caso (religioso, económico, etcétera), los difusores de especies negativas eran objeto de señalamiento moral: la "malicia" o las "malas intenciones" solían ser rasgos salientes en ellos y las autoridades no perdían oportunidad de subrayarlo. También en la campaña varias circulares emitidas por el síndico García de Zúñiga mostraban esa preocupación. En los siguientes documentos se advierte, no obstante, que el anónimo podía ser condenado o reivindicado con toda naturalidad según fuese el bando en que militara su emisor. En un sentido moral, semejante al que acabamos de ver en el comunicado del Cabildo, el autor llamó "venales" a los escritores pertenecientes al grupo de Caballeros Orientales:

“[...] una pequeña facción de anarquistas de Montevideo [...] ha esparcido entre otras falsedades, la noticia de que el Emperador ha decretado la evacuación [...] [25-XI-1822]; [...] acabo de saber por conductos confidenciales de toda credibilidad que el jefe de la facción anarquista de Montevideo es Don Carlos Alvear [...] [28-XI-1822];

[...] El Cabildo de Montevideo paga ya escritores venales para defender la doctrina de su superioridad sobre todos los pueblos de la Banda Oriental [y apela a] todos los resortes de la intriga y de la seducción [...] [19-XII-1822].”35

Aun con el cambio de escenario registrado en 1823 -un gobierno militar que toleraba la publicación de críticas duras contra los abrasilerados y un nuevo Cabildo cuya orientación era apoyada por los principales escritores públicos-, los publicistas montevideanos se mantuvieron dentro de los límites que la ley de 1821 había impuesto en materia de responsabilidad autoral. Al momento de dar a conocer

\footnotetext{
${ }^{33}$ El 16 de diciembre del mismo año la corporación suspendió su obediencia a Lecor y al Síndico Procurador, Tomás García de Zúñiga, argumentando que desde setiembre ya no existía el Reino Unido de Portugal, Brasil y Algarve al que se había unido la provincia en el discutido congreso de 1821. REYES ABADIE, Washington; BRUSCHERA, Oscar; MELOGNO, Tabaré, La emancipación oriental (1820-1830), Montevideo, Editorial Medina, 1966, p. 26.

${ }^{34}$ BNM-SU, El Exmo. Cabildo, Montevideo, 8 de noviembre de 1822.

${ }^{35}$ BNM-SU, Circulares del Sindico Procurador del Estado a los Cabildos [1822], s/f, s/l. Énfasis añadidos.
} 
opiniones propias y ajenas, la anonimia se mantuvo y más de una vez se recordó a los lectores que se evitarían los riesgos innecesarios: "si [quien firma como] Desengañador insiste en que se dé a luz [su carta]", advirtió La Aurora, "no tendremos inconveniente en hacerlo siempre que suscriba sus producciones con una firma, que con arreglo a la Ley consideramos de suficiente garantía”. ${ }^{6}$ Del mismo modo, El Pampero exigió que las denuncias o protestas contra personas públicas fueran firmadas por sus autores "para evitar compromisos" y "salvar responsabilidades" ${ }^{37}$, aunque los nombres de los denunciantes nunca aparecían en los correos de lector. No siempre se tuvo esta precaución, lo que habría de ocasionar inconvenientes a los editores y reacciones de ciertas autoridades, como enseguida veremos.

En más de una oportunidad, realizar afirmaciones fundadas solamente en trascendidos públicos no verificados generó dificultades a los papelistas. En agosto de 1822, cuando Lecor aún se encontraba en la ciudad, El Patriota -editado por Manuel Torres, tipógrafo de origen bonaerense que por entonces también era el arrendatario de la imprenta del Cabildo- definió que "un periódico que no habl[ara] de política al presente, e[ra] lo mismo que un fusil sin cañón”. Sin embargo, no ignoraba que al elegir sus temas de análisis "deb[ía] caminar con pies de plomo"38, pese a lo cual cometió algún error que debió subsanar con prontitud. Informó que el capitán general, ya instalado en Canelones, buscaba reducir el número de tropas de Montevideo apelando a diversas maniobras, una de las cuales consistía en ofrecer la baja a quienes abandonaran la ciudad. De inmediato recibió una carta de un lector que desmintió la especie. Torres admitió su equivocación y la atribuyó al exceso de confianza en "las noticias que corrían por el pueblo", a las que había dado crédito por "no tene[r] a [su] disposición los archivos". Enfatizó que "jamás [se] extender[ía] más allá de los límites de la libertad [...] permitida", porque se consideraba "muy celoso de [su] seguridad". En otra breve nota incluida en el mismo número volvió a señalar el peligro de "conducir[se] por relaciones las más veces inexactas". 39

\footnotetext{
${ }^{36}$ La Aurora, $1^{\circ}$ de marzo de 1823, p. 50, "Remitidos".

${ }^{37}$ El Pampero, 15 de enero de 1823, p. 20, "Contestación”.

${ }^{38}$ El Patriota, 23 de agosto de 1822, pp. 7-8, “Contestación”. Énfasis en el original.

${ }^{39}$ El Patriota, 27 de setiembre de 1822, p. 33, "Remitido" y "Contestación”; y p. 31, "Montevideo". Énfasis añadido.
} 
Aun en espacios tan reducidos como el Montevideo cisplatino, las publicaciones sin firma parecían brindar ciertas garantías a los críticos de las autoridades. El Aguacero, publicación de perfil político-humorístico que según Antonio Zinny fue editada por Antonio Díaz, Santiago Vázquez y Juan Francisco Giróto, se expidió con claridad y en más de un tono sobre esta cuestión. Manifestó su propósito de censurar los errores, las injusticias y la deshonestidad de funcionarios y magistrados, y hacerlo "con aquella libertad y confianza que solo es capaz de infundir la idea de seguridad que goza el escritor anónimo contra los tiros del odio, la animosidad y la venganza”.41 Hallaba "gracia" en

"esto de poder un hombre decir cuanto le viniere a las mentes, haciendo estirar el hocico a unos y mostrar los dientes a otros, sin que nadie, por más que se cal[entas]e la mollera, pu[dier]a caer en cuenta de quién ser[ía] el grandísimo tumbón que de este modo se ha[bía] propuesto criticar lo malo y elogiar lo bueno".42

De esta manera se prolongaba una actividad, la de ser papelista, que era por definición inestable, muchas veces breve y con frecuencia peligrosa. En ocasiones podía haber pugnas entre el interés de los lectores por saber quién o quiénes estaban detrás de estas publicaciones, y el de sus redactores por evitarlo:

\begin{abstract}
"Cuando yo el editor, que Dios guarde, me vi amenazado de ser descubierto, juzgué que diciendo que yo mismo me delataría de grado y no por fuerza sería bastante [...] para contener el enjambre de curiosos y mal entretenidos, que se empeñaban en averiguar mi catadura".
\end{abstract}

Sin abandonar su tono burlón, el autor reconocía que en aquel ámbito ningún editor podría mantenerse en las sombras por mucho tiempo. Para lograrlo también dependía de otros, especialmente de sus colaboradores, lo que sin duda aumentaba

\footnotetext{
${ }^{40}$ ZINNY, Antonio, Historia de la prensa periódica de la República Oriental del Uruguay, 1807-1852, Buenos Aires, Imprenta y Librería de Mayo, 1883, pp. 1-2. Los contenidos y sobre todo el estilo de El Aguacero son lo suficientemente diferentes como para establecer al menos algún matiz de duda respecto de su autoría. Dardo Estrada parece haber tenido las mismas reservas, ya que en su clásica obra sobre la imprenta oriental enumeró los periódicos de 1822-1823 sin ninguna mención al posible redactor de este órgano: "La Aurora: 1822-1823. Redactor: Antonio Díaz, 17 números. [...]. El Pampero: 1822-1823. Redactores: Santiago Vázquez, Antonio Díaz, Juan Francisco Giró, 14 números. El Ciudadano: 1823. Redactor: Santiago Vázquez, 9 números. [...] Aguacero: 1823, 8 números [...]" (ESTRADA, Dardo, Historia y bibliografia de la imprenta en Montevideo, 1810-1865, Montevideo, Librería Cervantes, 1912, p. 19).

${ }^{41}$ El Aguacero, 19 de julio de 1823, p. 29, s/t.

${ }^{42}$ El Aguacero, 26 de abril de 1823, p. 9, "Política".
} 
las dificultades: "me preparé también a burlar [las] asechanzas, seguro de que ninguno de $[. .$.$] mis corresponsales me faltaría al secreto".43$

Las dudas en torno a la verdadera identidad del editor o los editores de $E l$ Aguacero no son solo historiográficas. Cuando este órgano comenzó a circular, otros medios cercanos al grupo de Caballeros Orientales se apresuraron a distanciarse de él... al menos públicamente. En el primer número de El Ciudadano, Santiago Vázquez desmintió "la opinión de los que a tientas [le] califica[ba]n entre otros autor del Aguacero", al que reprochó su "espíritu de causticidad". Antonio Díaz, desde La Aurora, criticó al "escritor chocarrero" que buscaba "ganar algunos medios [dinero] excitando la curiosidad pública con pifias y dicharachos”. Ni Díaz ni Vázquez dieron a conocer el nombre del redactor de El Aguacero y tampoco realizaron cuestionamientos políticos al periódico. Por el contrario, para el segundo de ellos se trataba de un "importante papel", "elocuente e ingenioso", lleno de "verdades amargas y útiles" sobre la situación de la provincia.44 ¿Es posible que ambos editores, $\mathrm{u}$ otros que también fueron vinculados públicamente con este órgano (como Juan Francisco Giró) hayan tenido razones para negar su participación en un periódico que, efectivamente, les pertenecía? ${ }^{45}$ La respuesta es afirmativa y los motivos pueden haber sido diversos. Uno de ellos, no menor, sería el deseo de evitar que la respetabilidad de algún miembro de la élite quedase comprometida por intervenir en una publicación de aspecto vulgar. Tradicionalmente, los periodistas no habían gozado de alta valoración dentro de la república de las letras y aunque en el siglo XIX mejoraron su posición como escritores serios, los excesos lingüísticos en que

\footnotetext{
${ }^{43}$ El Aguacero, 18 de junio de 1823, p. 21, s/t.

${ }^{44}$ El Ciudadano, $1^{\circ}$ de junio de 1823, p. 1, "El editor"; La Aurora, 29 de abril de 1823, p. 75, "Aguacero".

${ }^{45}$ La información disponible no permite afirmar rotundamente que otros Caballeros Orientales hayan intervenido en la publicación de El Aguacero, o que Vázquez, Díaz y Giró lo hayan redactado anónimamente, como sostuvo Zinny. Un dato diferente aporta Álvarez Ferretjans al señalar que los autores habrían sido Díaz, Giró y Francisco Solano Antuña (ÁLVAREZ FERRETJANS, Daniel, Historia de la Prensa en el Uruguay. Desde la Estrella del Sur a Internet, Montevideo, Búsqueda - Fin de Siglo, 2008, p. 78). Agreguemos que en los casos de ediciones colegiadas tampoco es posible determinar el grado de participación de cada autor. Según Martha Campos, la colaboración de Vázquez con El Pampero debió realizarse a distancia en algunos momentos, pues se hallaba en Buenos Aires mientras el periódico se imprimía a comienzos de 1823 (CAMPOS DE GARABELLI, Martha, ob. cit., p. 416). Por su parte, Álvarez Ferretjans (ob. cit., pp. 74-76) informa que en ausencia de Vázquez fueron Díaz y Giró quienes se ocuparon de todas las labores editoriales. En sus Memorias, Antonio Díaz se refirió a "cuatro periódicos [montevideanos] redactados por D. Santiago Vázquez, D. Antonio Díaz, D. Juan Giró, y D. Diego Benavente (chileno) y otras hojas sueltas". Archivo General de la Nación, Uruguay (en adelante AGNU), Fondo Archivos Particulares, Archivo del Brig. Gral. Antonio Díaz, caja 329, carpeta 1. Memorias del Brig. Gral. Antonio Díaz, tomo 1, f. 173.
} 
frecuentemente incurrían El Aguacero y otros impresos anónimos podían acercarlos peligrosamente a lo que Voltaire llamó canaille de la littérature. 46

Entre agosto y setiembre de 1823, Da Costa reforzó los controles sobre la actividad de imprenta y sobre la publicación de rumores y anónimos. Téngase en cuenta que un año después de la independencia brasileña la coyuntura política había variado significativamente: mientras algunos emisarios del Cabildo montevideano (entre ellos, Santiago Vázquez) buscaban apoyo para su proyecto revolucionario en las provincias de Entre Ríos, Santa Fe y Buenos Aires, el ayuntamiento -que mantenía relaciones de cierta cordialidad con el jefe portugués- esperaba que la posible partida de los Voluntarios Reales hacia Lisboa le devolviera el control de la ciudad. Pero en Europa se había operado un cambio significativo desde que en mayo de ese año la Vilafrancada, movimiento militar de corte absolutista, forzó la disolución de las Cortes47, al tiempo que se aceleraba la caída del régimen liberal español gracias al apoyo que la Quíntuple Alianza y la masiva intervención militar francesa prestaron a Fernando VII. En este marco, apenas iniciado el mes de agosto, Da Costa hizo saber que garantizaría "a los individuos reunidos en sociedad [...] el libre uso de escribir e imprimir sus pensamientos", pero no aceptaría que se violaran "los límites prescriptos a esta noble facultad" por la normativa de 1821, y por ello mandó instalar "a la brevedad posible [el] tribunal que la mencionada ley dispon[ía]". Se lograría así que cada ciudadano quedase "a cubierto de la malignidad a que el hombre tiene su natural tendencia". ${ }^{8} \mathrm{~A}$ dos años de aprobada la ley parecía necesario recordar su vigencia y advertir sobre "la maledicencia" de quienes solían recurrir al infundio o la tergiversación. Vale destacar que esta preocupación no era exclusiva del general portugués. La publicación de comentarios mordaces, así como las quejas de los agraviados, venían siendo objeto de comentarios desde el año anterior. Otro comentarista anónimo, "El Conciliador", hizo una temprana advertencia a los "nuevos publicistas", instándolos a no "zaherir el honor de las personas, injuriar las familias, manchar recíprocamente [su] reputación, y chismografear en público". Lamentaba que una peligrosa "tempestad de papeles impresos e infamantes" pudiera

\footnotetext{
${ }^{46}$ Para un análisis de esta problemática en la Francia dieciochesca: DARNTON, Robert, Edición y subversión. Literatura clandestina en el Antiguo Régimen, México, Turner - FCE, 2003, capítulo I.

${ }^{47}$ PIMENTA, João Paulo G., Estado e Nação no fim dos impérios ibéricos no Prata (1808-1828), San Pablo, Editora Hucitec, 2002, p. 199.

${ }^{48}$ Los Amigos del Pueblo, 9 de agosto de 1823, p. 5, "Oficio mandado publicar por el gobierno". Da Costa firmó el decreto una semana antes.
} 
desatar "una lluvia de palos [de] unos con otros". Temía que desapareciera "para siempre aquella dulce paz y encantadora tolerancia" que, a su juicio, los montevideanos habían disfrutado desde la pacificación del territorio en 1820 y que las imprentas y sus productos perdieran capacidad civilizadora para transformarse en agentes regresivos. 49

Curiosamente, el mismo día que Da Costa publicó su advertencia apareció en Los Amigos del Pueblo (órgano editado por Francisco Solano Antuña y José Catalá y Codina $^{50}$ ) un texto titulado "Imperiales de adentro" en el que se comentaba uno de los asuntos más sensibles para las autoridades: el rumor sobre posibles negociaciones entre Lecor, Da Costa y el Cabildo para hallar una salida al conflicto existente. El autor de la nota también involucró a los comerciantes - a quienes acusó de lucrar con el enfrentamiento entre Montevideo y la campaña-, a los vecinos acaudalados que pagando dos pesos mensuales quedaban eximidos del "alistamiento cívico" y a ciertos oficiales que abusaban de su jerarquía para "ir a mezclarse entre nuestros enemigos, y volver a ocupar sus puestos". ${ }^{51}$ En virtud de la "notable trascendencia" de estas versiones, el jefe de los Voluntarios Reales ordenó descubrir a los autores del rumor e "inmediatamente [formarles] la competente causa, que se remitir[ía] concluida a [1]a superioridad, a fin de resolver fueran castigados rigurosamente, y evitar en lo sucesivo se espar[cier]an noticias falsas". ${ }^{52}$ Se desconoce el resultado de esa investigación, pero Catalá y Codina se apresuró a desmentir las versiones que le atribuían la autoría de aquella especie. Lo hizo de un modo que nos permite ver cómo el rumor y la anonimia podían complementarse en aquellas prácticas comunicacionales. Rechazó las denuncias y también aprovechó las ventajas de la escritura sin nombre de autor para ocultar la identidad de los responsables del periódico; esto es, según lo que hoy sabemos, la suya propia:

“como esto es una falsedad que hiere mi delicadeza y moderación, solo me queda el
recurso, para convencer de lo contrario, de presentarme ante el público y asegurar [...]
que no soy yo el autor de dichos escritos [el citado "Imperiales de adentro"]. [También] se
ha hecho circular por el pueblo [que yo] descubrí los autores de Los Amigos del Pueblo.

\footnotetext{
${ }^{49}$ BNM-SU, Documentos históricos, pieza 43, El Conciliador o el amigo de la paz a los Nuevos Publicistas [hoja suelta], 4 de noviembre de 1822 .

${ }^{50}$ ZINNY, Antonio, ob. cit., p. 3.

${ }^{51}$ Los Amigos del Pueblo, 9 de agosto de 1823, p. 6, "Imperiales de adentro".

${ }^{52}$ Los Amigos del Pueblo, 16 de agosto de 1823, p. 9, "Ha llegado a nuestras manos copia del siguiente oficio que nos hacemos el honor de publicar".
} 
Esto es un error, o mejor diré una imposición que solo puede ser admitida por aquellas personas que ignoren la firmeza de mi carácter [...]”.

Como cierre del pequeño debate, un añadido de los editores confirmaba los dichos del acusado: "nos consta hasta la evidencia que el señor Catalá no es el autor de los escritos [que] han causado resentimientos en algunos individuos”. .53

No solamente las publicaciones periódicas enfrentaron problemas de esta índole. Algo similar ocurrió con La Plutónica. Oda dirigida a Plutón, un anónimo folleto político de tono satírico y procaz, profundamente crítico de la monarquía hispánica, que dio pie a una operación de censura que vale examinar. La obra fue aparentemente "escrita el año [18]16", según se lee en nota al pie de su primera página y reimpresa en 1823 por los tipógrafos Valentín y Rosendo Ayllón (en la "Imprenta de los Ayllones"). Recoge claramente el espíritu de los viejos pasquines infamantes antigubernamentales (un tipo de publicación que Teófanes Egido encuadra dentro de la "prensa ocasional"54), en una arremetida fundamentalmente dirigida a los reyes españoles, desde los Católicos en adelante. Si bien uno de los versos alude a la totalidad de los monarcas ("esos reyes hebreos, esos godos, / y cuantos rey se dicen, vengan todos”), ningún soberano portugués aparece mencionado, pese a lo cual fue rechazada de plano por los representantes de Lisboa en Montevideo.

Escrita en primera persona, La Plutónica invoca obviamente a Plutón, versión romana del Hades de los griegos, el despiadado dios de los infiernos al que se pide reúna "los jueces inflexibles" con el fin de sentenciar "a los reyes con espanto". Luego, en orden cronológico, los monarcas son llamados a juicio. Siguiendo una práctica también tradicional en esta clase de publicaciones 55 se subrayan brevemente aspectos negativos de cada uno: Fernando el Católico, "fundador del laberinto", junto a "su esposa, la Isabel ambiciosa”; Carlos I ("vil flamenco villano"), Felipe II (“de quien se

\footnotetext{
${ }^{53}$ Los Amigos del Pueblo, 16 de agosto de 1823, p. 12, "Comunicado". Catalá firmó la nota de descargos con su nombre completo, algo que - como se ha dicho- sucedía raras veces.

${ }^{54}$ EGIDO LÓPEZ, Teófanes, Opinión pública y oposición al poder en la España del siglo XVIII (1713-1759), Valladolid, Universidad de Valladolid y Fundación Española de Historia Moderna, 2002, pp. 41-46. Ver también REVILLA, Paola, "Pasquines reformistas, pasquines sediciosos: aquellas hojas volanderas en Charcas (siglos XVIII-XIX)", Ciencia y Cultura, Universidad Católica Boliviana, nos. 22-23, 2009, p. 34.

55 "El matiz personal es el alma de este género histórico. Las personas constituyen su objetivo directo. [Los autores] tienen un fin muy preciso: denigrar de manera sistemática e irrazonable" (EGIDO LÓPEZ, Teófanes, ob. cit., pp. 44-45).
} 
sabe fijo / que asesinó a su hijo"), "Felipe tercero / poeta estrafalario y majadero", seguidos por "Felipe cuarto, débil y medroso" y "Carlos segundo, eterno vagamundo". Después comparecen los Borbones: Felipe V ("no dormía, y sobre un tambor comía"), Fernando VI ("el Midas de todas las naciones conocidas"), Carlos III ("señor napolitano [que] vino como nube de verano / a chupar la colmena / por don Fernando llena"), Carlos IV, "el borbón de los borbones / y el padre universal de los cabrones", y cierra Fernando VII, que ciñe la corona en forma "absoluta / sin embargo de ser hijo de p...” [sic].56

Da Costa decretó la incautación de toda la tirada del folleto y su envío a la secretaría del gobierno. La medida se fundamentaba en el carácter ofensivo de una composición que tenía todas las características de un libelo: "con la mayor indecencia se ataca la autoridad de los monarcas, sin guardar el menor decoro a la primera dignidad de una Nación”. El jefe portugués insistió en la necesidad de instalar el tribunal de imprenta previsto en la norma de 1821 para que el autor de La Plutónica, o quien hubiera costeado su impresión, "respond[iera] por la transgresión de la Ley". Lo único cierto era que el documento había salido de la Imprenta de los Ayllones. A lo largo del mes fueron ubicadas y requisadas varias copias, algunas en la librería de Manuel Yáñez -que por entonces era el punto de venta más importante de la ciudady otras en los domicilios de compradores identificados por el propio comerciante. El resumen de las actuaciones registradas por el escribano Ignacio Márquez permite conocer el cariz de los procedimientos:

“[...] el Sr. Gobernador Intendente personalmente pasó a la Imprenta de los Ayllones y compañía [y] recogió tres ejemplares del título La Plutónica; y enseguida hizo igual diligencia a la librería de Dn. Manuel Yáñez e hizo igual operación de los que estaban sin venderse, expresando que solo seis había expendido [18 de agosto]. En 19 de dicho mes y año, y por relación del librero Dn. Manuel Yáñez, se recogió un impreso que había sido comprado por Dn. Juan el Inglés [...]. Seguidamente pasé a casa de Dn. José Vidal a exigirle el impreso que había comprado, y me contestó que lo había rompido [sic]. Inmediatamente pasé a casa de D. Juan Buenaventura Vidal, y héchole saber el objeto de mi comisión, me entregó el impreso que había comprado. [...] Los ejemplares [...] que han

\footnotetext{
${ }^{56}$ Biblioteca del Colegio Nacional, Buenos Aires - Fondo Donación Juan Canter. La Plutónica. Oda dirigida a Plutón, ¿agosto? de 1823, s/p.
} 
podido recoger[se], los he mandado pasar a la Secretaría de V.E. según me lo ha ordenado en su superior oficio [...]. 29 de agosto de 1823".57

Todo indica que la acción judicial contra los editores del folleto no pudo llevarse a cabo. Según el propio Da Costa, el Cabildo informó que la ausencia de personas idóneas impedía designar el tribunal competente "en los pocos días que [él] suponía". Pero en lugar de tomar otras medidas punitivas optó por "levant[ar] la suspensión ordenada [el] 26 del corriente" ${ }^{8} 8$ y esperar a que efectivamente se formara el tribunal. Falta información más detallada sobre el proceso de selección, pero conocemos su llamativo resultado final. La Junta Electoral, reunida en setiembre, elaboró la lista de cuarenta y ocho Jueces de Hecho que prescribía la ley. Luego de sortear algunas dificultades formales se conformó una nómina que incluyó a varios destacados miembros del grupo de Caballeros Orientales, algunos de ellos con notoria participación en el Cabildo (renovado mediante elecciones celebradas en enero de 1823), y otros como animadores principales de la actividad periodística: Giró, Antuña, Vázquez y Díaz figuraban en la lista junto a Juan B. Blanco, Lorenzo Pérez, Gabriel Pereira, Francisco Muñoz, Gregorio Lecoq, León de Ellauri y Prudencio Murguiondo, entre otros. ${ }^{59}$ Parece evidente que los planes de Da Costa para combatir los rumores y las especies incendiarias (más allá de su real voluntad o capacidad para llevarlos a cabo) no se favorecieron de las demoras en conformar el tribunal, ni del perfil de sus integrantes.

A finales de 1823 tuvieron lugar nuevos cambios en el escenario político regional. En noviembre, Lecor y Da Costa alcanzaron un acuerdo que devolvió al capitán general la máxima autoridad de la provincia en representación de Pedro I; la División de Voluntarios Reales evacuó la ciudad y regresó a Lisboa; entre los elegidos para integrar el nuevo Cabildo no apareció ninguno de los Caballeros Orientales, que en su mayor parte abandonaron el territorio oriental. Además, el 9 de mayo de 1824 se juró en la Provincia Cisplatina la Constituição Politica do Imperio, aprobada en Brasil el 24 de marzo. La carta, que nunca llegó a regir plenamente en el territorio

\footnotetext{
${ }^{57}$ AGNU - Fondo Escribanía de Gobierno y Hacienda (en adelante EGH), caja 136, expediente 271, fs. 1-3. Decreto de Álvaro da Costa ordenando incautación del folleto titulado La Plutónica, Montevideo, agosto de 1823.

${ }^{58}$ No hemos hallado el referido documento del 26 de agosto, pero cabe suponer que ordenaba el cierre temporal del taller de los Ayllones. AGN-EGH, caja 136, expediente 276, f. 1. Oficio de Álvaro da Costa al Intendente de Montevideo, 29 de agosto de 1823.

${ }^{59}$ Fue publicada en Los Amigos del Pueblo, 20 de setiembre de 1823, p. 29, s/t.
} 
oriental, estableció que cada Estado debía tener un presidente elegido por el Emperador y un consejo provincial con administraciones locales a cargo de consejos de distrito. Para el primero de estos cargos, en noviembre de 1825 fue elegido el general Francisco de Paula Magessi, un portugués que entre 1817 y 1820 había sido gobernador de Mato Grosso. En la senda de lo establecido por las Cortes tres años antes, el nuevo texto constitucional consagró la libertad de prensa. No obstante, en la práctica fue un derecho limitado y sujeto a permanentes tensiones durante el reinado de Pedro I. ${ }^{60}$

En ese contexto disminuyó drásticamente la actividad de imprenta. El taller tipográfico del Cabildo quedó prácticamente paralizado mientras que otros dos, el de los hermanos Ayllón y la Typographia do Estado - controlada directamente por el gobierno de Lecor- se mantuvieron en funcionamiento pese a la notable retracción verificada tras la derrota del movimiento revolucionario de 1822-1823. A lo largo de 1824 existieron únicamente dos medios de prensa en la ciudad, El Publicista Mercantil de Montevideo y Gazeta de Montevideo; fueron los últimos antes del repunte editorial de 1826. El primero de ellos reviste mayor interés en nuestro caso. Fue el primer diario editado en el territorio oriental: apareció de lunes a sábados, desde enero hasta marzo de 1824, con el objetivo de abordar temas comerciales y otros de diversa índole. ${ }^{61}$

Su editor fue el ya mencionado maestro José Catalá y Codina, quien desde 1821 dirigía la escuela pública. Al principio contó con importante apoyo de las autoridades civiles y religiosas; Lecor y Dámaso Antonio Larrañaga, cura vicario de Montevideo, dieron respaldo político y económico al modelo lancasteriano allí implantado. Pero en 1824 la institución enfrentaba severas dificultades materiales. Parece evidente que la participación de Catalá en el movimiento periodístico antibrasileño no había sido olvidada por quienes retomaron el control de la ciudad. Mermadas las contribuciones en dinero y criticados tanto el proyecto educativo como su principal responsable, las páginas de El Publicista... funcionaron como tribuna en defensa de la escuela y único espacio de contestación a los rumores adversos. Catalá atribuyó los ataques anónimos a la ignorancia y mala fe de algunas personas y a la incapacidad de los incautos para

\footnotetext{
${ }^{60}$ Véase RIBEIRO, Lavina Madeira, ob. cit., pp. 63-72.

${ }^{61}$ AGNU - Fondo Ex Archivo General Administrativo, caja 587, carpeta 3. Prospecto de "El Publicista Mercantil" [sic], Montevideo, s/f.
} 
distinguir la mentira de la verdad. En dos artículos publicados en febrero enumeró y trató de rebatir cada uno de los agravios. Objetó a quienes afirmaban que "en esta escuela no se enseñ[aba] doctrina cristiana, cuando no ha[bía] niño de los que leen, a quien no se h[icier]a estudiar de memoria el catecismo", o se dijera que el sistema "era de invención inglesa y, por consiguiente, que era anticatólico", proclive a fomentar "el libertinaje y la herejía" (énfasis en el original). En un ámbito como el montevideano, la acusación de anticatolicismo pro-inglés era algo grave y el director lo sabía. Aludió a los comentarios críticos con expresiones sinónimas como "hacer correr la voz", "se hizo circular por la ciudad" y "divulgar en la ciudad". En ningún caso identificó a los autores, pero destacó el carácter urbano de estos, su dinamismo (hacían "correr" o "circular" sus ideas) y el tipo de público al que intentaban engañar ("alucinar a la plebe"). Precisamente, a la masa popular debían destinarse los mayores esfuerzos pedagógicos: “¿Por qué les incomodar[ía] tanto a ciertos hombres este sistema de educación [...]? Solo el pensar ellos que la plebe, las clases labradora y artesana pu[dier]an dentro de poco aprender todos a leer, escribir y contar, choca[ba] a su ignorancia". ${ }^{62}$ Catalá perdió la batalla: en marzo, poco después de completarse el cambio de autoridades con el reingreso de Lecor a Montevideo se canceló la edición de El Publicista... y el director de la escuela fue apartado del cargo, decretándose primero su destierro y luego el encarcelamiento.

Hasta 1826 no existió en Montevideo un periódico netamente oficialista. En agosto de ese año nació el Semanario Mercantil de Montevideo, de José Raymundo Guerra, síndico procurador del Cabildo desde el $1^{\circ}$ de enero de 1824. Este órgano, merecedor de un estudio particular que aún no ha sido realizado, fue, luego del españolista Gazeta de Montevideo (1810-1814), el de más extensa vida antes de la independencia. Su último número apareció en febrero de 1829 , fecha en la que probablemente Guerra ya se había desvinculado de la redacción. ${ }^{63}$

\footnotetext{
${ }^{62}$ El Publicista Mercantil de Montevideo, 20 de febrero de 1824, s/p, "Defensa del sistema de Lancaster y respuesta a los ataques que, a la sordina, le hacen los ignorantes", y 24 de febrero de 1824, s/p, "Continúa la defensa del sistema Lancasteriano".

${ }^{63}$ José Raymundo Guerra fue un individuo de trayectoria singular. Nacido en España, probablemente en la década de 1750, llegó al Plata en 1772. Integró el Regimiento Veterano de Infantería de Buenos Aires hasta 1780. Más tarde fue asistente y hombre de confianza del saladerista Francisco Medina, e inició una singular carrera en el ámbito judicial, donde actuó defendiendo a varios esclavizados. Fue un "entendido en pleitos sin título alguno", al decir de Arturo Bentancur ("Amos y esclavos en el viejo Montevideo. El combate por la libertad, 1790-1820", Arturo BENTANCUR; Fernando APARICIO, Amos y esclavos en el Río de la Plata, Buenos Aires, Planeta, 2006, p. 37). En 1808, la junta montevideana lo envió a España con el objetivo de
} 
El prospecto del Semanario Mercantil anunció que acabaría con el "silencio tan profundo" de las imprentas, pero con apego estricto al orden promovido por el gobierno imperial. Por tanto, "todas las reflexiones ser[ía]n tendentes al bien de la causa del Brasil", para lo cual era imprescindible "exclu[ir] los libelos, las sátiras, las mordacidades y detracciones". La historia de los posteriores enfrentamientos entre Guerra y la prensa republicana mostraría cuán lejos de la realidad quedó esta aspiración del síndico, destinatario de las burlas e insultos más variados de sus enemigos. Pero en 1826, al iniciar su carrera como escritor (aunque anónimo, claro está), pretendía que los periodistas del Semanario "no contestar[a]n ninguna Sátira", puesto que la imprenta debía ser garantía del "orden que demanda[ba] la razón". ${ }^{64}$ Ya había manifestado su rechazo de los rumores en mayo de 1825, cuando mandó imprimir una proclama en la que condenó el alzamiento iniciado por Juan Antonio Lavalleja el mes anterior. En ella se refirió al asombro que ocasionó "el primer rumor de la asonada con que han sido sorprendidos los tranquilos ánimos de nuestros comprovincianos". ${ }^{65}$ No obstante, veremos que también él repudió los rumores y anónimos con criterio selectivo.

El Semanario subrayó que los promotores de voces y versiones insidiosas no necesariamente estaban en la provincia. Quienes lanzaban noticias falsas en o desde territorios limítrofes podían provocar un daño similar, o aún mayor, pues resultaba casi imposible repeler sus ataques: "con la mentirología y la chismografía se introduce la sedición en una provincia amiga", mientras las intrigas se "mantiene[n] a la capa" (vale decir, a la espera de una ocasión propicia), comentó "Un Amigo" a propósito de varias notas publicadas en Buenos Aires por El Mensajero Argentino. ${ }^{66}$ Pero lo mismo, o algo peor si se considera el vínculo entre Montevideo y Rio de Janeiro, sucedía con algunos medios cariocas. Cuando el Diário Fluminense imprimió las críticas de un desconocido corresponsal acerca de individuos "ambiciosos" que conspiraban contra el orden y la paz de la capital cisplatina, algunos

exponer las razones del enfrentamiento con Buenos Aires; de allí regresó el año siguiente, junto al virrey Cisneros. Durante los tiempos artiguistas se dedicó al comercio y retornó a la vida política en 1824, quizás ayudado por su amigo, el párroco Larrañaga, con quien redactó unos Apuntes históricos sobre la Banda Oriental del Río de la Plata, desde el descubrimiento de ese territorio hasta el año 1818 (véase también BENTANCUR, Arturo, "José Raymundo Guerra: un «Don Nadie» en la colonia", Hoy es Historia, año III, n 18 , diciembre de 1986, pp. 38-44).

${ }^{64}$ [Semanario Mercantil], iagosto? de 1826, s/p, "Prospecto".

${ }^{65}$ BNM-SU, El Síndico Procurador General de esta Capital a nombre del Exmo. Cabildo. Proclama, Montevideo, 6 de mayo de 1825.

${ }^{66}$ Semanario Mercantil de Montevideo, 17 de febrero de 1827, p. 112, "Señor Editor". 
“Ciudadanos Montevideanos" exigieron que se investigara el origen de las denuncias. Enviaron una extensa carta en la que demandaron detalles sobre el autor de la nota y los presuntos delincuentes, "para no ofender en general a todos los habitantes" de la ciudad. Pedían castigo para los culpables, ya fueran los denunciados o el responsable del texto si este resultaba calumnioso. Decían haber "reflexionado lo siguiente" a propósito de quienes lanzaban acusaciones valiéndose de seudónimos o del simple anonimato:

\begin{abstract}
"El que escribe, para no abusar de la Imprenta [...] es menester firme los Papeles, porque ellos tienden contra la reputación y el honor de otro: y en esto debiera ser inexorable el Tribunal destinado a la Policía pública [...]. Todos estamos obligados [a] prestarnos con nuestras luces, y [...] manifestar clara y distintamente los traidores de la Nación, [...] pero nadie está autorizado en casos tan delicados [a] infamar a otro con perjuicio de la tranquilidad pública [...]. El que obra tan descaradamente contra el orden público, merece ser punido por su audacia y mala fe [...]”.67
\end{abstract}

En esta ocasión, como era costumbre, los "Ciudadanos Montevideanos" enfatizaron los defectos morales del comentarista ("descaro", "mala fe"). Pero, como signo de los tiempos, en numerosas oportunidades el periódico justificó el ocultamiento de identidades cuando convino a los intereses políticos imperiales: la expresión "por noticias extractadas de una carta particular escrita de sujeto de crédito se asegura que ..." ${ }^{68} \mathrm{y}$ otras del mismo tenor aparecieron reiteradas veces en el semanario de Guerra.

Es sabido que los escritos anónimos no necesariamente se presentaban en prosa. Otros formatos, como los versos y los diálogos ficticios - estos últimos muy habituales en los catecismos políticos- eran bien aceptados por todos los sectores sociales y fueron también muy utilizados. ${ }^{69}$ Asimismo, circularon varias hojas sueltas firmadas por misteriosos duendes: "El duende de antaño", "El duende de todas las horas", "El duende de día" o "El duende exentero [destripador]". Redactadas en español o portugués, fueron otra herramienta empleada por quienes combatían la anexión al Brasil. Mediante escenificaciones y conversaciones imaginadas atacaban a los abrasilerados, apelando con frecuencia al ridículo. Pero estos duendes, como

\footnotetext{
${ }^{67}$ Semanario Mercantil de Montevideo, 30 de noviembre de 1826, p. 25, "Comunicado interesante".

${ }^{68}$ Semanario Mercantil de Montevideo, 14 de abril de 1827, p. 147, "Variedades". Énfasis añadido.

${ }^{69}$ SILVA PRADA, Natalia, ob. cit., pp. 229-230.
} 
señala Ana Frega, encontraron respuestas de algunos brujos que representaban la posición imperial. Véase un ejemplo: con respecto a la negativa bonaerense de prestar apoyo militar a los Caballeros Orientales en 1823, "El más aficionado de los Brujos" dijo a "El más amado de los duendes": "tú sabes que por acá los orientales no gustan de esa gente [los porteños], porque dicen los dejaron en la estacada, no los ayudaron en otro tiempo, $y$ hasta algunos creen que los vendieron [...]".70

Cerraremos este apartado presentando el Diálogo ocurrido en Montevideo, un imaginario intercambio entre José Raymundo Guerra y el presidente Magessi (presentado como "Maggense"). Impreso en Canelones, este folleto de ocho páginas fue uno de los primeros productos de la republicana "Imprenta de la Provincia". No está fechado, pero sus contenidos y el lugar de edición sugieren que apareció entre agosto y noviembre de 1826, cuando ya existía el Semanario Mercantil pero no aún la Gaceta de la Provincia Oriental. Muestra el intercambio entre dos personeros del régimen imperial atribulados por la situación del momento y, sobre todo, por su incierto futuro personal. Guerra es presentado como redactor del Semanario. Cuando Magessi le transmite noticias acerca del avance de los revolucionarios, tanto en los aspectos militares como a nivel de opinión pública, Guerra le responde: "yo no creo nada de eso [...] Todo lo que se dice son voces que hacen correr entre nosotros los partidarios de los insurgentes. ¿Cree V.E. señor general, que si eso fuese así, no lo publicarían al momento los periódicos orientales?" La siguiente pregunta de su interlocutor revela preocupación por la influencia del periodismo bonaerense: “¿Qué periódicos, hombre de Dios, si no hay ninguno en la provincia? Vea V. como ya lo ha hecho el Mensajero Argentino; pero, por nuestra fortuna, este periódico corre muy poco por aquí". De inmediato se hace alusión al origen de los rumores -que no siempre debía adjudicarse a las malas intenciones del adversario-, y al modo en que llegaban a conocimiento de las autoridades mediante informantes pagos:

"No seamos tan confiados, ni despreciemos los rumores que corren; que no son, como
dice V., invenciones de los partidarios de nuestros enemigos. Ya que hemos tocado esta
materia, le contaré, acá para los dos, todo lo que mis emisarios de la campaña me han
informado hoy mismo; y esto lo debe V. creer como oficial, porque los [...] que me hacen

\footnotetext{
${ }^{70}$ FREGA, Ana, "Proyectos políticos y faccionalismo militar. Ecos de la crisis de la monarquía portuguesa en Montevideo, 1820-1824", Illes i Imperis, $\mathrm{n}^{\circ}$ 17, 2015, pp. 84-85. El documento citado por la autora puede verse completo en BNM-SU, Documentos históricos, pieza 34. El más aficionado de los brujos a el Más amado de los duendes, Montevideo, [1823].
} 
este servicio, están prevenidos de que si alguno me engaña o me desfigura los hechos, además de podrirlo en un calabozo, pierde para siempre los cien pesos mensuales con que les gratifico el servicio de espionaje".

Oídas las informaciones y explicaciones que Magessi tiene para darle, Guerra pierde la confianza que mostraba al comienzo de la charla. Finalmente, acuerdan callar para evitar el caos: "Guerra: iJesús! qué chucho me ha entrado! Pero, ¿̇es cierto eso señor Maggense? / Maggense: Ojalá no lo fuera! Pero es necesario, amigo, que ocultemos al público estos hechos y les hagamos creer lo contrario [...]”.71

\section{Para finalizar}

Al igual que los lenguajes, los proyectos políticos, las configuraciones territoriales y la economía, también los estados de ánimo de las personas, sus deseos y sus capacidades productoras/receptoras de mensajes sufrieron todas las tensiones propias del largo ciclo revolucionario-independentista. Como se sabe, la comunicación mediante el rumor y el escrito anónimo era largamente conocida en las sociedades occidentales, pero nunca fue, ni podía ser, un elemento aislado de las circunstancias en que ambos elementos surgieron, circularon y provocaron (o pudieron provocar) reacciones del más diverso tipo. El recorte temporal seleccionado en esta oportunidad permitió concentrar el análisis y advertir con claridad las principales características del objeto de estudio. Entendemos que este tipo de enfoque puede resultar válido para el examen de otros períodos (por ejemplo, la totalidad del ciclo revolucionario rioplatense), en estudios más abarcadores (comparación entre procesos regionales, historias generales de la prensa) o bien puede brindar insumos para historiar la escritura "de autor".

Se ha procurado abordar el análisis del escrito anónimo como momento comunicacional intermedio entre la pura oralidad del rumor - voz poseedora de varios sentidos, pero asociada naturalmente con la anonimia- y la formalización del texto de autor conocido. La prensa periódica y los demás componentes de la publicística revolucionaria decimonónica oriental facilitaron ese tránsito. Hemos visto que los crecientes esfuerzos (legales, policiales, culturales) por combatir la

\footnotetext{
${ }^{71}$ BNM-SU: Diálogo ocurrido en Montevideo entre el general Maggense y don José Raymundo Guerra editor del Semanario Mercantil, con motivo de los informes que el general Lecor pide al primero desde Puerto Alegre sobre el estado politico y militar en la Banda Oriental, Canelones, ca. 1826, fs. 2-4 y 6.
} 
crítica, el sarcasmo y el insulto sin nombre de autor debieron transigir con ciertas tradiciones afianzadas. Dicho con palabras de Chartier, existían brechas entre los dogmas y las creencias, entre lo que se ordenaba desde el poder y lo que efectivamente se hacía.72 Asimismo, consideramos que es dable analizar estos procesos dentro de la pequeña y convulsionada sociedad montevideana del primer tercio del siglo XIX incorporando puntos de vista concebidos para el estudio de casos diferentes del que nos ocupa. Así, con Farge y Revel diremos que "la persistencia del rumor confirmó la naturaleza social de la comunicación oral” y fue, por sobre todas las cosas, "una expresión de la emoción y la credulidad que formaba parte del estereotipo psicológico de las personas del momento". 73

Pudo verse que todos los actores, a su turno, supieron aprovechar las ventajas proporcionadas por unos medios de comunicación que no dudaron en cuestionar cuando lo creyeron oportuno. En este sentido, los papelistas montevideanos, incluso los más cercanos al poder político, actuaron como si dispusieran de poder para validar o censurar el modo en que las noticias se difundían. Muchos integrantes de aquella sociedad -autoridades, escritores, lectores, público en general-sabían, o al menos sospechaban, que las voces de la calle podían ser no más que una pura invención de quienes tenían motivos poderosos para echarlas a rodar, o que tal vez buscaban desacreditar un rumor que efectivamente tenía bases firmes. Así lo señaló un publicista de los tiempos cisplatinos: "si es verdad que [cierta especie] se ha propagado [...], debe atribuirse a la propensión de dar realidad a los fantasmas del deseo, o acaso a la imaginación ardiente del [autor], queriendo prevenir un mal que debe temer". 74

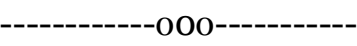

\section{Bibliografía citada}

ACREE, William, La lectura cotidiana. Cultura impresa e identidad colectiva en el Río de la Plata, 1780-1910, Buenos Aires, Prometeo, 2013.

\footnotetext{
${ }^{72}$ CHARTIER, Roger, La historia o la lectura del tiempo, Barcelona, Gedisa, 2007, p. 66.

${ }^{73}$ FARGE, Arlette; REVEL, Jacques, ob. cit., p. 95.

${ }^{74}$ El Pampero, $1^{\circ}$ de enero de 1823 , p. 12 , s/t.
} 
ÁlVAREZ FERRETJANS, Daniel, Historia de la Prensa en el Uruguay. Desde la Estrella del Sur a Internet, Montevideo, Búsqueda - Fin de Siglo, 2008.

BENTANCUR, Arturo, La familia en el Río de la Plata a fines del período hispánico. Historias de la sociedad montevideana, Montevideo, Planeta, 2011.

BENTANCUR, Arturo, “José Raymundo Guerra: un «Don Nadie» en la colonia”, Hoy es Historia, año III, nº 18, diciembre de 1986, pp. 38-44.

BENTANCUR, Arturo, "Amos y esclavos en el viejo Montevideo. El combate por la libertad (1790-1820)", Arturo BENTANCUR; Fernando APARICIO, Amos y esclavos en el Río de la Plata, Buenos Aires, Planeta, 2006, pp. 17-206.

CAMPOS DE GARABELLI, Martha, La Revolución Oriental de 1822-1823. Su génesis, tomo I, Montevideo, Junta Departamental, 1972.

CASTILLO GÓMEZ, Antonio, "Desde el muro. Formas y mensajes de la escritura expuesta en la ciudad altomoderna", Gemma PUIGVERT; Carme DE LA MOTA (ed.), La investigación en Humanidades, Madrid, Editorial Biblioteca Nueva, 2009, pp. 91-110.

CASTILlO GÓMEZ, Antonio, "Panfletos, coplas y libelos injuriosos. Palabras silenciadas en el Siglo de Oro", Manuel PEÑA DÍAZ (ed.), Las Españas que (no) pudieron ser: herejías, exilios y otras conciencias (s. XVI-XX), Huelva, Servicio de Publicaciones de la Universidad de Huelva, 2009, pp. 59-73.

CHARTIER, Roger, La historia o la lectura del tiempo, Barcelona, Gedisa, 2007.

DARNTON, Robert, Edición y subversión. Literatura clandestina en el Antiguo Régimen, México, Turner - FCE, 2003.

DÍAZ, César L., Comunicación y revolución, 1759-1810. Esfera y espacio público rioplatense: periodismo, censura, prácticas y ámbitos de lectura, La Plata, Universidad Nacional de La Plata, 2012.

ESTRADA, Dardo, Historia y bibliografía de la imprenta en Montevideo, 1810-1865, Montevideo, Librería Cervantes, 1912.

FARGE, Arlette; REVEL, Jacques, The Vanishing Children of Paris. Rumor and Politics before the French Revolution, Cambridge (Mass.), Harvard University Press, 1991.

FEBVRE, Lucien, El problema de la incredulidad en el siglo XVI. La religión de Rabelais, Madrid, Akal, 1993. 
FREGA, Ana, "La vida política”, Gerardo CAETANO (dir.), Ana FREGA (coord.), Uruguay: revolución, independencia y construcción del Estado. Tomo I, 1808/188o, Montevideo, Mapfre, 2015, pp. 31-85.

FREGA, Ana, "Proyectos políticos y faccionalismo militar. Ecos de la crisis de la monarquía portuguesa en Montevideo, 1820-1824”, Illes i Imperis, $\mathrm{n}^{0}$ 17, 2015, pp. 57-90.

GARAVAGLIA, Juan Carlos, “Los primeros senderos de la revolución: La Opinión en los balbuceos de la Independencia rioplatense (1806-1819)", Izaskun ÁLVAREZ CUARTERO; Julio SÁNCHEZ GÓMEZ (ed.), Visiones y revisiones de la independencia americana, Salamanca, Ediciones de la Universidad de Salamanca, 2003, pp. 111-143.

GONZÁLEZ BERNALDO, Pilar, "La Revolución Francesa y la emergencia de nuevas prácticas de la política: la irrupción de la sociabilidad política en el Río de la Plata revolucionario, 1810-1815”, Boletín del Instituto de Historia Argentina y Americana “Dr. Emilio Ravignani”, $3^{\mathrm{a}}$. serie, $\mathrm{n}^{\circ}$ 3, 1991, pp. 7-27.

GONZÁLEZ CRUZ, David, Propaganda e información en tiempos de guerra. España y América (170o-1714), Madrid, Sílex, 2009.

GONZÁLEZ DEMURO, Wilson, "La prensa en tiempos de la Provincia Cisplatina. El Pacífico Oriental de Montevideo y los ecos del constitucionalismo portugués en el Río de la Plata”, Improntas de la historia y la comunicación, $\mathrm{n}^{\circ} 2$, Universidad Nacional de La Plata, Facultad de Periodismo y Comunicación, diciembre-mayo 2016, pp. 1-33. Disponible en http://perio.unlp.edu.ar/ojs/index.php/improntas/index

GONZÁLEZ DEMURO, Wilson, La prensa de Montevideo, 1814-1825. Imprentas, periódicos y debates públicos en tiempos de revolución (inédito).

GUERRA, François-Xavier, “«Voces del pueblo». Redes de comunicación y orígenes de la opinión en el mundo hispánico (1808-1814)”, Revista de Indias, vol. LXII, no 225, 2002, pp. 357-384.

LANGUE, Frédérique, “ «Del pasado hay que hacer añicos». Historiadores, prensa y revolución en Venezuela”, Nadia AÏT BACHIR (ed.), Las fuentes en la prensa: verdades, rumores y mentiras, Burdeos, Département d'Études ibériques, ibéro-américaines \& méditerranéennes / UFR Langues et civilisations, Université Michel de Montaigne-Bordeaux 3, 2013, pp. 7-23. 
MOREL, Marco, "La génesis de la opinión pública moderna y el proceso de independencia (Río de Janeiro, 1820-1840)”, François-Xavier GUERRA, Annick LEMPÉRIÈRE y otros, Los espacios públicos en Iberoamérica. Ambigüedades y problemas. Siglos XVIII y XIX, México, Centro Francés de Estudios Mexicanos y Centroamericanos - Fondo de Cultura Económica, 1998, pp. 300-320.

OLIVARI, Michele, Avisos, pasquines y rumores. Los comienzos de la opinión pública en la España del siglo XVII, Madrid, Cátedra, 2014.

PIMENTA, João Paulo G., Estado e Nação no fim dos impérios ibéricos no Prata (1808-1828), San Pablo, Editora Hucitec, 2002.

REVILLA, Paola, "Pasquines reformistas, pasquines sediciosos: aquellas hojas volanderas en Charcas (siglos XVIII-XIX)”, Ciencia y Cultura, Universidad Católica Boliviana, nos. 22-23, 2009, pp. 33-43.

REYES ABADIE, Washington; BRUSCHERA, Oscar; MELOGNO, Tabaré, La emancipación oriental (1820-1830), Montevideo, Editorial Medina, 1966.

RIBEIRO, Lavina Madeira, Imprensa e espaço público: a institucionalização do jornalismo no Brasil (1808-1964), Rio de Janeiro, E-Papers Serviços Editoriais, 2004.

SCOTT, James, Los dominados y el arte de la resistencia, México, Ediciones ERA, 2000.

SILVA PRADA, Natalia, "La escritura anónima: ¿especie sediciosa o estrategia de comunicación política colonial?”, Andes. Antropología e Historia, no 16, 2005 , pp. 223-252.

TENGARRINHA, José, História da imprensa periódica portuguesa, Lisboa, Caminho, 1989.

THOMPSON, Edward, “El delito de anonimato”, Tradición, revuelta y consciencia de clase, Barcelona, Crítica, 1984, pp. 173-238.

ZINNY, Antonio, Historia de la prensa periódica de la República Oriental del Uruguay, 1807-1852, Buenos Aires, Imprenta y Librería de Mayo, 1883.

ZIRES, Margarita, "Las dimensiones del rumor: oral, colectiva y anónima”, Oralidad, anuario 8. Lenguas, identidad y memoria de América, La Habana, UNESCO Editorial Pueblo y Educación, 1996, pp. 23-29. 


\section{Fuentes periodísticas (impresas en Montevideo)}

El Pacífico Oriental de Montevideo, 1821-1822.

La Aurora, 1822-1823.

El Pampero, 1822-1823.

El Patriota, 1823.

El Aguacero, 1823.

El Ciudadano, 1823.

La Plutónica. Oda dirigida a Plutón, ¿̇agosto? de 1823

Los Amigos del Pueblo, 1823.

El Publicista Mercantil de Montevideo, 1824.

Semanario Mercantil de Montevideo, 1826-1829.

\section{Archivos}

Archivo General de la Nación, Uruguay. Fondo Archivos Particulares.

Archivo General de la Nación, Uruguay. Fondo Escribanía de Gobierno y Hacienda.

Archivo General de la Nación, Uruguay. Fondo Ex Archivo General Administrativo.

Biblioteca del Colegio Nacional, Buenos Aires. Fondo Donación Juan Canter.

Biblioteca Nacional, Montevideo. Sala Uruguay. 